\title{
Phenolic Acids and Depsides from Some Species of the Erodium Genera
}

\author{
Izabela Fecka*, Adam Kowalczyk and Wojciech Cisowski \\ Department of Pharmacognosy, University of Medicine, pl. Nankiera 1, 50-140 Wroclaw, \\ Poland. Fax: (0 48) 713445 830. E-mail: izabela@bf.uni.wroc.pl \\ * Author for correspondence and reprint requests \\ Z. Naturforsch. 56c, 943-950 (2001); received July 26/August 8, 2001 \\ Erodium, Phenolic Acids, Plant Polyphenols
}

Six natural polyphenolic compounds, brevifolin carboxylic acid, brevifolin, ellagic acid, methyl gallate, gallic acid and protocatechuic acid have been isolated from the methanol extract of the whole plant of Erodium cicutarium (L.) L.'Hérit. (Geraniaceae). Structures were determined by conventional methods of analysis and confirmed by MS and NMR spectral analysis. The distribution of these compounds in the other species of the Erodium genera (E. botrys, E. chium, E. ciconium, E. cicutarium, E. glutinosum subsp. dunense, E. gruinum, E. manescavi, E. pelargoniiflorum, E. petraeum) were examined by HPLC with a RP-18 column, and MGD-TLC methods on unmodified silica gel and silica gel chemically modified with polar and nonpolar groups (HPTLC-Si 60 LiChrospher, HPTLC-NH ${ }_{2}$, HPTLC-DIOL, HPTLC RP-18W).

\section{Introduction}

E. cicutarium (Common stork's bill) is a one- or two-year herb growing up to about $50 \mathrm{~cm}$ and indigenous to Europe, Asia and North America. Other species of the Erodium genera are Mediterranean plants. Decoction from the aerial parts of E. cicutarium plant has been recommended for treatment of dysentery, fever, wounds and worm infections as a traditional medicine (Lis-Balchin, 1993; 1994). In Middle Europe it was employed as antihaemorrhagic drug in gynecology to stop the uterine bleeding and as general haemostipticum. Ellagitannin-containing plants, such as these from the genera Erodium are used for preparing astringent and antiseptic teas announced in stomatitis (Klocke et al., 1986). Both water and methanol extract from E. cicutarium demonstrated antiviral effect in relation to Herpes virus type 1, Vesicular stomatitis, Vaccinia virus and myxoviruses (Zielinska-Janczylik et al., 1987). Non of these extracts did induce interferon in suspension of human leukocytes. However, the methanol extract exerted a stimulatory effect on the synthesis of interferon induced with Newcastle disease virus in cell cultures. The strongest viricidal fractions contain some polyphenols, excluding flavonoid glycosides (Zielinska-Janczylik et al., 1988). In immunological tests the low concentrations of methanol extract from E. cicutarium stimulated whereas the high concentrations inhibited free radicals activity of human granulocytes in vitro (Fecka et al., 1997). This observation was in agreement with previously described antioxidant properties of several species from Erodium. The polyphenolic fraction from flowering aerial parts of these species exerted in vitro a free radical scavenging effect on the 1,1diphenyl-2-picrylhydrazyl (DPPH) radical (Lamaison et al., 1993) and an inhibitory effect on the $\mathrm{Fe}^{+2}$ - induced lipid oxidation (Sroka et al., 1994). Previous papers reported the presence of ellagitannins, flavonoid glycosides, phenolic acids and essential oil (Lis-Balchin, 1993). Salech et al. (1983) studied the flavonoids of fourteen Erodium from two sections: Pulmosa Boiss. and Erodium (=Barbata Boiss.). Ellagic acid $(0.77 \%)$ was detected in hot methanol extract of E. cicutarium by GC (Klocke et al., 1986). The total concentration of flavonoids, tannins and geraniin in E. chium, $E$. ciconium and E. cicutarium were determined using both colorimetric and chromatographic methods (Lamaison et al., 1993). In this work we have defined the polyphenols content of methanol extracts from nine species of Erodium. Phenolic acids and depsides have been examined with help of qualitative and quantitative analytical techniques. 


\section{Material and Methods}

\section{Plant material}

The following species from the Erodium genera (Geraniaceae) were analyzed: E. botrys (Cav.) Bertol., E. ciconium (L.) L.'Hérit., E. cicutarium (L.) L.'Hérit., E. chium Sibth. et Sm. non Willd., E. glutinosum subsp. dunense (Andreas) Rothm., E. gruinum (L.) L.'Hérit., E. manescavi Cosson, E. pelargoniiflorum Boiss. et Heldreich, E. petraeum (Gouan) Willd.. All herbs at the flowering stage were collected in Poland in September 1996-1998. E. cicutarium (L.) L.'Hérit. was obtained from a natural habitat (a voucher specimen is deposited in our Department). Another species were cultivated from selected seeds (Jardin Botanique Nantes, France) at the herbarium of the University of Medicine in Wroclaw.

\section{Preparation of extracts}

Phenolic compounds, derivatives of phenol carboxylic acid and hydroxycinnamic acids were prepared from $5 \mathrm{~g}$ dried and powdered herbs of each species from the Erodium genus according to the method described by Van Sumere et al., (1972). Free phenolic acids and phenolic acids obtained after the hydrolytic cleavage of $O$-glycosides or esters were designated in diethyl ether extracts. Enzyme hydrolysis: $\beta$-glucosidase (Koch-Light, Colnbrook Bucks, England); the acetic buffer; $\mathrm{pH} 4.5$; $37^{\circ} \mathrm{C} ; 10 \mathrm{~h}$. Alkaline hydrolysis: $2 \mathrm{M} \mathrm{NaOH}$; $\mathrm{pH}$ 12; room temperature; $120 \mathrm{~min}$. Methanol extracts were prepared by a well-known procedure. The second portions $(5 \mathrm{~g})$ of powdered row materials were first exhaustively extracted (Soxhlet) with $\mathrm{CH}_{2} \mathrm{Cl}_{2}$ and next with methanol on the waterbath. After filtration crude methanol extracts were concentrated under reduce pressure at $40^{\circ} \mathrm{C}$, and the $0.1 \mathrm{~g}$ from each obtained residues dissolved in $10 \mathrm{ml}$ of HPLC grade methanol (Merck, Darmstadt, Germany).

\section{Isolation of polyphenols}

The isolation of compounds A-F (Fig. 1) was performed only for Erodium cicutarium herb. The other species were analyzed with help of chromatographic techniques. Powdered and dried aerial parts $(800 \mathrm{~g})$ of E. cicutarium were extracted successively with $n$-hexane, $\mathrm{CH}_{2} \mathrm{Cl}_{2}$ and methanol in a Soxhlet apparatus. The crude methanol extract was filtered, dryness under reduce pressure at $40^{\circ} \mathrm{C}$, dissolved in water $(300 \mathrm{ml})$ and partitioned with diethyl ether (liquid-liquid extractor). The diethyl ether fraction of the methanol extract from E. cicutarium ( $6 \mathrm{~g}$ from total ratio $22.5 \mathrm{~g}$ ) was separated on silica gel column ( $\mathrm{Si} 60,0.15-0.30 \mathrm{~mm}$; Macherey-Nagel, Düren, Germany) using stepwise gradient elution with $\mathrm{CH}_{2} \mathrm{Cl}_{2}$ containing increasing concentration of methanol $-10 \%, 20 \%$, $30 \%$ to $60 \%$. Seven fractions were collected $(\mathrm{Fr}-1 \rightarrow \mathrm{Fr}-7)$. The fractions consisting of polyphenols were finally purified on octadecyl (RP-18, 40 $\mu \mathrm{m}, 60$ A, LC J. T.Baker, Phillipsburg, USA) with solvent systems consisted of methanol and water. Subsequent purification by a combination of silica gel and octadecyl chromatografies afforded 4 individual compounds: compound $\mathbf{A}$ (115 mg) from Fr-2 using 10\% methanol as the eluent, compound B $(85 \mathrm{mg})$ from Fr-3 using $10 \%$ methanol, compound $\mathbf{C}(800 \mathrm{mg})$ from Fr-5 using $10 \%$ methanol, compound D $(30 \mathrm{mg})$ from Fr-6 using $20 \%$ methanol. Compound $\mathbf{E}(65 \mathrm{mg})$ was separated from compound $\mathbf{F}(31 \mathrm{mg})$ on the $\mathrm{NH}_{2}$ microcolumn (500 mg, $3 \mathrm{ml} \mathrm{J.} \mathrm{T.Baker,} \mathrm{Phillipsburg,} \mathrm{USA).} \mathrm{In}$ these conditions constituent $\mathbf{F}$ was selectively absorbed from the methanol solution of $\mathrm{Fr}-7$ on a propylamine bad and washed with methanol-formic acid (99.5:0.5; v/v). Compound $\mathbf{E}$ was crystallized from the methanol eluate. Structure of isolated constituents were elucidated based on chemical evidences and spectral analyses.

\section{Standard solutions}

Polyphenolic stock standard solutions $(1 \mathrm{mg} / \mathrm{ml})$ were prepared by dissolving $5 \mathrm{mg}$ of each standards in $5 \mathrm{ml}$ of HPLC grade methanol (Merck, Darmstadt, Germany). Working standard solutions were prepared by dilution with methanol and filtered through membrane filters (Millipore, 0.22 $\mu \mathrm{m})$. All standards of phenolic acids were purchased from Extrasynthése (Lyon, France).

\section{Apparatus and conditions}

IR and UV spectra were measurement on a Unicam SP 1000 spectrometer and a Perkin Elmer UV/VIS Lambda 20 spectrophotometer. ESIMS were recorded on a AMD 604 mass spectrometer and ESMS on a AMD 404 mass spectrometer. ${ }^{1} \mathrm{H}$-, 
${ }^{13} \mathrm{C}$-NMR spectra were obtained on a Bruker WM 52 spectrometer.

In TLC were used following HPTLC precoated plates (Merck, Darmstadt, Germany), $20 \times 10 \mathrm{~cm}$ : silica gel Si 60, LiChrospher Si 60, aminopropyl silica, octadecyl RP-18W and HPTLC DIOL $10 \times$ $10 \mathrm{~cm}$. They were spotted with 10-20 $\mu \mathrm{l}$ samples of diethyl ether extracts, $5-15 \mu l$ solutions of individual standards and their mixture as $8-10 \mathrm{~mm}$ bands. Chromatograms were developed in horizontal teflon DS-chambers (Chromdes, Lublin, Poland) with the gradient mobile phase program I, II, III (Table I) or two time with eluent IV water-methanol-formic acid (89:10:1; v/v/v), over a path of $9 \mathrm{~cm}$. Plates were dried in a stream of warm air for $5 \mathrm{~min}$ after each step. Colored compounds were detected under UV light (254, $365 \mathrm{~nm}$ ) and by spraying with $1 \%$ methanol $\mathrm{FeCl}_{3}$ (Fig. 2), or with bis-diazotized sulfanilamide (Fig. 3).
The HPLC system consisted of two pumps (Knauer, Berlin, Germany), a sample injector and a variable wave length UV detector (Knauer variable wavelength monitor type 87.00) connected to a personal computer (HPLC Software/Hardware Package Version 2.21A). Separations were achieved using a LiChroCART ${ }^{\circledR}$ 250-4 100 RP$18(5 \mu \mathrm{m})$ column with a LiChroCART ${ }^{\circledR} 4-4100$ RP-18 $(5 \mu \mathrm{m})$ pre-column (Merck, Darmstadt, Germany). Detection was carried out by on-column measurement of UV absorption at $280 \mathrm{~nm}$. The sensitivity was set at 0.04 a.u.f.s. The flow rate was adjusted to $1.0 \mathrm{ml} / \mathrm{min}$. Phenolic acids and depsides were separated using an acetonitrilewater gradient with formic acid addition according to program V (Table II). A $20 \mu \mathrm{l}$ volume of analyzed samples was injected. The calibration graphs of polyphenols were prepared by measuring the peak area and they were linear in the examined range $(0.02-0.10 \mathrm{mg} / \mathrm{ml})$. For the HPLC analyses

Table I. Gradient elution programs for the MGD-TLC method when using various plates. Plates were dried after each step.

Program I. Four-step gradient program for silica gel plates.

\begin{tabular}{ccccccc}
\hline Eluent: & \multicolumn{2}{c}{$\%(v / v)$} & & Volume & Development & Time \\
\hline Step No & Cyclohexane & $\begin{array}{c}\text { Diisopropyl } \\
\text { ether }\end{array}$ & $\begin{array}{c}\text { Formic } \\
\text { acid }\end{array}$ & {$[\mathrm{ml}]$} & distance $[\mathrm{mm}]$ & {$[\mathrm{min}]$} \\
\hline 1 & - & 80 & 20 & 1 & 20 & 3 \\
2 & 20 & 78 & 2 & 5 & 90 & 20 \\
3 & 20 & 78 & 2 & 5 & 90 & 20 \\
4 & 20 & 79 & 1 & 5 & 90 & 20 \\
\hline
\end{tabular}

Program II. Two-step gradient program for propylamine plates.

\begin{tabular}{|c|c|c|c|c|c|}
\hline Eluent: & \multicolumn{2}{|c|}{$\%(v / v)$} & Volume & Development & Time \\
\hline Step No & Acetone & Acetic acid & [ml] & distance $[\mathrm{mm}]$ & {$[\mathrm{min}]$} \\
\hline $\begin{array}{l}1 \\
2\end{array}$ & $\begin{array}{l}85 \\
90\end{array}$ & $\begin{array}{l}15 \\
10\end{array}$ & $\begin{array}{l}5 \\
5\end{array}$ & $\begin{array}{l}90 \\
90\end{array}$ & $\begin{array}{l}15 \\
15\end{array}$ \\
\hline
\end{tabular}

Program III. Four-step gradient program for diol plates.

\begin{tabular}{cccccc}
\hline Eluent: & \multicolumn{2}{c}{$\%(v / v)$} & Volume & Development & Time \\
\hline \multirow{2}{*}{ Step No } & $n$-Hexane & $\begin{array}{c}\text { Ethyl-methyl } \\
\text { ketone }\end{array}$ & {$[\mathrm{ml}]$} & distance $[\mathrm{mm}]$ & {$[\mathrm{min}]$} \\
\hline 1 & 30 & 70 & 1 & 20 & 2 \\
2 & 60 & 40 & 2 & 90 & 15 \\
3 & 70 & 30 & 2 & 90 & 15 \\
4 & 80 & 20 & 2 & 90 & 15 \\
\hline
\end{tabular}


Table II. The gradient elution program V for the HPLC method with the RP-18 column. The composition of mobile phase (v/v); solvent A: acetonitrile-formic acid (95:5), and solvent B: water-formic acid (95:5).

\begin{tabular}{llcll}
\hline & Time & \multicolumn{2}{c}{ Eluent } & Type of elution \\
\cline { 1 - 2 } Step No & $(\min )$ & & $(v / v)$ & \\
\hline 1 & $0-2$ & $10 \%$ & A in B & isocratic elution \\
2 & $2-17$ & $10 \%-30 \%$ & A in B & linear gradient \\
3 & $17-20$ & $30 \%-70 \%$ & A in B & linear gradient \\
\hline
\end{tabular}

gradient grade acetonitrile was used. Water was glass distilled and deionized. Solvent solutions were vacuum degassed with sonication prior to usage. All experiments were performed at room temperature $\left(20^{\circ} \mathrm{C}\right)$.

\section{Results and Discussion}

Phenolic acids and depsides in the Erodium genus were investigated by chromatographic techniques. We carried out an isolation and an identification of main constituents of diethyl ether fraction from the methanol extract of E. cicutarium. The composition of polyphenols from the other species of Erodium was established using HPLC and MGD-TLC methods. Dried and powdered aerial parts of plants were extracted with methanol under reflux. Polyphenolic compounds were partitioned between $\mathrm{Et}_{2} \mathrm{O}$ and water. Phenolic acids and depsides were examined before and after hydrolysis of tannins (Van Sumere et al., 1972). The diethyl ether fraction from E. cicutarium was chromatographied on silica gel by the $\mathrm{CC}$ method. Elution with $\mathrm{CH}_{2} \mathrm{Cl}_{2}$ containing increasing proportions of methanol separated polyphenols according to their polarity. Eluates consisting of phenolic acid or depsides were finally separated on octadecyl with a solvent system containing methanol and water. Subsequent purification by combination of octadecyl and silica gel chromatographies afforded 6 individual compounds (A-F). Structures of these principles (Fig. 1) were elucidated by chemical methods (mainly co-chromatography, hydrolytic degradation, melting point) and spectroscopic methods (UV, IR, MS, NMR). These separated constituents were identified as methyl gallate $(\mathbf{A})$, protocatechuic acid (B), gallic acid (C), brevifolin carboxylic acid (D), brevifolin (E) and ellagic acid (F) by di-

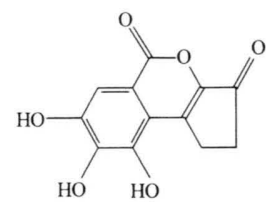

E Brevifolin

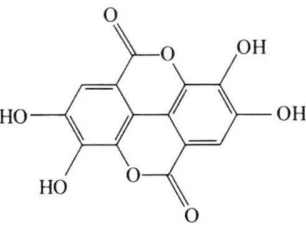

F Ellagic acid

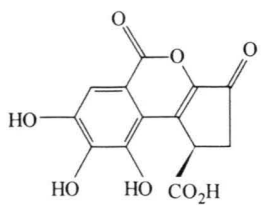

D Brevifolin carboxylic acid
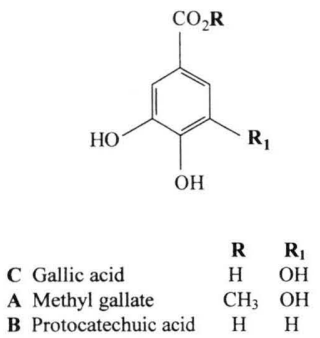

Fig. 1. Structures of phenolic acids and depsides identified in the Erodium species.

rect comparison of their physical and spectral profiles with literature values (Klocke et al., 1986; Shimizu et al., 1989; Nawwar et al., 1994; Lin and Lin, 1997). We have also examined the distribution of phenolic acids and depsides in the other species of Erodium.

Unmodified silica gel and silica gel chemically modified with polar (amino, diol) and nonpolar ( $n$-octadecyl) groups were employed for analysis of polyphenols by TLC. The best separation of phenolic acids was achieved on silica gel Si 60

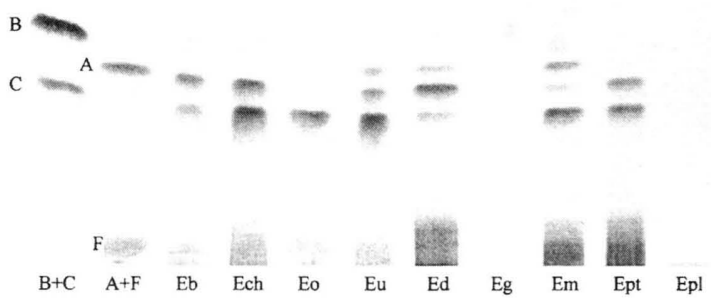

Fig. 2. Chromatrogram of methanol extracts from analyzed Erodium species and standards developed accordiong with program I on the HPTLC LiChrospher silica gel plate. Polyphenols were visualized by spraying with $\mathrm{FeCl}_{2}$ reagent. Tracks: A methyl gallate, B protocatechuic acid, $\mathbf{C}$ gallic acid, F ellagic acid, Eb E.botgrys, Ech E.chium, Eo E.ciconium, Eu E.cicutarium, Ed E. glutinosum subsp. dunense, Eg E. gruinum, Em E. manescavi, Ept E. petraeum, Epl E. pelargoniiflorum. 
LiChrospher and octadecyl plates using program I (Fig. 1) and mobile phase IV relatively. Satisfied results were observed for diol and program III. Depsides were determined on propylamine plates at program II (Fig. 3). HPLC-RP 18 separation with acetonitrile-water gradient was characterized good resolution for both phenolic acids and depsides. The optimal separation of the standard mixture was recorded for $5 \%$ concentration of formic acid as $\mathrm{pH}$ modifier (Fig. 4). The described MGDTLC method on the silica gel and chemically modified stationary phases is selective for separation of phenolic acids and depsides compared with commonly used unmodified layers. Because of, analyzed compounds are well separated from a complex mixture, the MGD-TLC method can be used for densitometric evaluations. The HPLC gradient for the characterization of polyphenolic com-

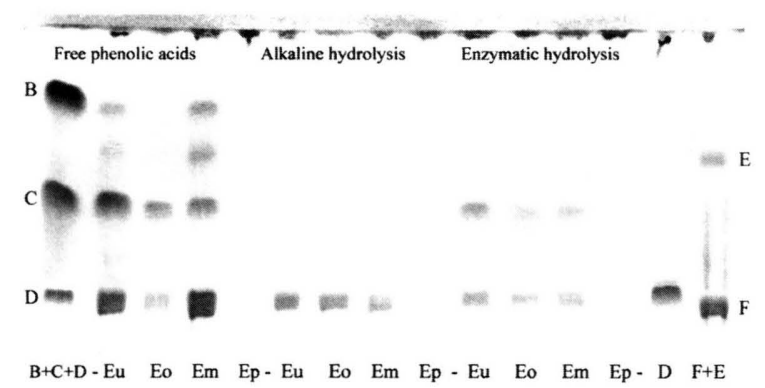

Fig. 3. Chromatogram of diethyl ether fractions from analyzed Erodium species and standards developed according with program II on the HPTL $\mathrm{NH}_{2}$ plate. Polyhenols were visualized by spraying with both $\mathrm{FeCl}_{2}$ and bis-diazotized sulfanilamide reagent. Tracks: B protocatechuic acid, $\mathbf{C}$ gallic acid, $\mathbf{D}$ brevifolin carboxylic acid, E bevifolin, F ellagic acid, Eo E.ciconium, Eu E.cicutarium, Em E.manescavi, Epl E.pelargoniiflorum.

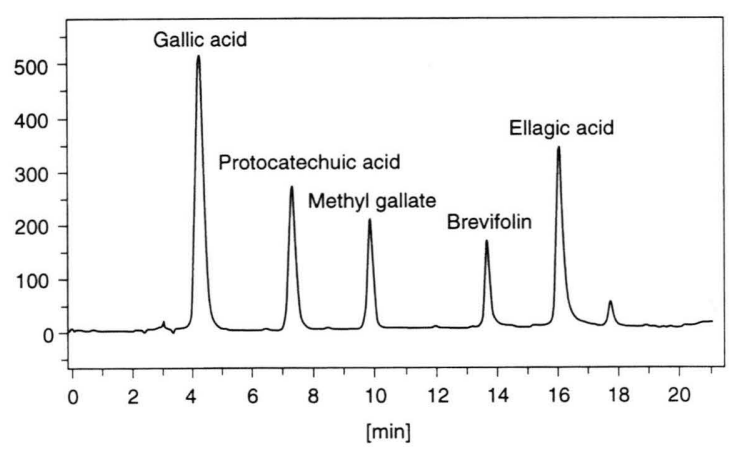

Fig. 4. HPLC chromatogram of diethyl ether fraction from $E$. cicutarium (RP-18, program V, $\lambda=280 \mathrm{~nm}$ ). pounds in an analyzed material can be applied for a chemosystematic study of other species from the Erodium genera in the polyphenols range.

Phenolic acids and depsides are secondary metabolites derived by hydrolysis of tannins. The Geraniaceae family afford ellagitanins with geraniin as a main constituent (Okuda et al., 1983; 1989b). Geraniin are hydrolyzed with dilute $\mathrm{HCl}$ yielding ellagic acid, brevifolin carboxylic acid, brevifolin, gallic acid and glucose (Okuda et al., 1989a). Investigated methanol extracts and diethyl ether fractions yield phenolic compounds in high concentration (Table III). Obtained results indicate that the major constituents of free phenolic acids are gallic acid, gallic acid methyl ester and protocatechuic acid. The second polyphenolic group are depsides: ellagic acid, brevifolin and its precursor brevifolin carboxylic acid. In low concentration appear following phenol carboxylic acids: salicylic; $m$ - and $p$-hydroxybenzoic; 2,3-dihydroxybenzoic; gentisic; vanillic and hydroxycinnamic acid derivatives: caffeic; $p$-coumaric; ferulic. Gallic acid and gentisic acid are present mainly as free or as $\beta$-glucosides. Protocatechuic acid and depsides form ester bonds. E. botrys, E. chium, E. cicutarium, E. glutinosum subsp. dunense, E. manescavi and $E$. petraeum have the similar qualitative composition of non-glycosylated polyphenols but they reveal quantitative differences. The highest content of depsides have been observed in $E$. manescavi and E. petraeum. The mean value for gallic acid is about $0.48 \%$ of dried weight of extracts and for ellagic acids $2.0 \%$ respectively. Methyl gallate has been detected in a high concentration in E. chium and E. petraeum. E. ciconium does not synthesize the methyl ester of gallic acid. It is interesting that E. gruinum and E. pelargoniiflorum possess only traces of phenolic acids with no presence of methyl gallate. The presence of gallic acid, protocatechuic acid, brevifolin carboxylic acid and caffeic acid were also described in $E$. moschatum (L.) L'Hérit by Jer-Huei Lin and MeiFan Lin (1997). Because, phenolic acids and depsides have been detected in the majority of tested methanol extracts their biologic significance may be discussed. These identified polyphenols possess antioxidant (Kimura et al., 1983a, 1983b; Hatano et al., 1989, 1990), antibacterial (Kolodziej et al., 1999), antiviral (Kane et al., 1988a; 1988b) and antiphlogistic actions (Okuda et al., 1983; 1989b). El- 
Table III. The contents of major phenolic acids and depsides in methanol extracts (mg per $1 \mathrm{~g}$ of dry weight) from nine species of the Erodium genera.

\begin{tabular}{|c|c|c|c|c|c|c|c|c|c|}
\hline \multirow[t]{2}{*}{ POLYPHENOLS } & $\begin{array}{c}E . \\
\text { botrys }\end{array}$ & $\begin{array}{c}E . \\
\text { ciconium }\end{array}$ & $\begin{array}{c}E . \\
\text { cicutarium }\end{array}$ & $\begin{array}{c}\text { E. } \\
\text { chium }\end{array}$ & $\begin{array}{c}\text { E. glutinosum } \\
\text { subsp. } \\
\text { dunense }\end{array}$ & $\begin{array}{c}\text { E. } \\
\text { gruinum }\end{array}$ & $\begin{array}{c}E . \\
\text { manescavi }\end{array}$ & $\begin{array}{c}\text { E. pelargo- } \\
\text { niiflorum }\end{array}$ & $\begin{array}{c}E . \\
\text { petraeum }\end{array}$ \\
\hline & \multicolumn{8}{|c|}{$[\mathrm{mg} / \mathrm{g}]$} & \\
\hline Gallic acid & 2.00 & 7.39 & 12.40 & 7.07 & 0.92 & 0.10 & 8.29 & 0.45 & 10.76 \\
\hline Protocatechuic acid & - & 0.65 & 3.93 & 0.67 & 2.28 & 0.39 & 0.08 & 0.98 & 1.46 \\
\hline Brevifolin & 3.62 & 8.41 & 25.95 & 7.12 & 6.79 & 0.45 & 50.74 & - & 13.99 \\
\hline Ellagic acid & 17.49 & 5.19 & 11.88 & 8.33 & 23.43 & 6.81 & 26.41 & 0.51 & 80.28 \\
\hline
\end{tabular}

(-) absent.

lagic acid, gallic acid and methyl gallate are also know as antimutagenic and anticarcinogenic plant agents. They prevent of a carcinogenesis process by inhibition of initiation or promotion stages (Perchellet et al., 1992). Additionally, gallic acid and its metabolites induce the death signal (apoptosis) via their prooxidant action in some cancer cell lines (Nogaki et al., 1998; Sakagami et al., 1997a, 1997b; Sakaguchi et al., 1998, 1999). The other studies show that ellagic acid significantly reduces acid secretion and $\mathrm{H}^{+}, \mathrm{K}^{+}$ATPase activity on gastric ulcers (Murakami et al., 1991). To sum up, we can conclude that isolated polyphenols might be considered as a potential substances of promising previously detected properties of methanol extracts from E. cicutarium and other species of Erodium. Also, one might speculate that dietary intake of such polyphenols reduces the risk of some forms of cancers and other various degenerative diseases.

\section{Compound A: Methyl gallate}

Pale needles, recrystallized from $\mathrm{MeOH}-\mathrm{H}_{2} \mathrm{O}$, mp. $>202{ }^{\circ} \mathrm{C}$;

$\mathrm{M}_{\mathrm{r}}$ 184.14, EI-MS $m / z: 184,153,125,107,97,79$, 51, 39;

TLC $\mathrm{R}_{\mathrm{f}}: 0.51$ (HPTLC Si $60 \mathrm{~L}$, program I), 0.55 (HPTLC DIOL, program III), 0.57 (HPTLC RP18 , eluent IV); brawn under $\mathrm{UV}_{365}$, dark blue after spraying with $\mathrm{FeCl}_{3}$ reagent, yellow with bisdiazotized sulfanilamide; HPLC $\mathrm{R}_{\mathrm{t}}$ : 9:51 (program $\mathrm{V})$; normal acid hydrolysis $\left(2 \mathrm{M}\right.$ aq. $\mathrm{HCl}, 100^{\circ} \mathrm{C}$, $2 \mathrm{~h})$ yielded gallic acid; UV $\lambda$ max $(\mathrm{MeOH}): 273$, $365 \mathrm{~nm}$. IR $v \max (\mathrm{KBr}): 3500-2800,2850,1700$, $1625,1540,1450,1375,1335,1270,1220,1100$, 1060, 1015, 920, 870, 780, $760 \mathrm{~cm}^{-1} ;{ }^{1} \mathrm{H}$ NMR
$\left(\mathrm{CD}_{3} \mathrm{OD}\right) \delta: 7.42(\mathrm{~s}, 2 \mathrm{H}, \mathrm{H}-2,6), 3.82(\mathrm{~s}, 3 \mathrm{H}$, $\left.\mathrm{OCH}_{3}\right)$.

\section{Compound B: Protocatechuic acid}

Colorless needles, recrystallized from $\mathrm{MeOH}$ $\mathrm{H}_{2} \mathrm{O}$, mp $214-216{ }^{\circ} \mathrm{C}$;

TLC $\mathrm{R}_{\mathrm{f}}$ : 0.58 (HPTLC Si $60 \mathrm{~L}$, program I), 0.76 (HPTLC $\mathrm{NH}_{2}$, program II), 0.51 (HPTLC DIOL, program III), 0.74 (HPTLC RP-18, eluent IV); brawn under $\mathrm{UV}_{365}$, dark blue after spraying with $\mathrm{FeCl}_{3}$ reagent, pink-gray with bis-diazotized sulfanilamide; HPLC $\mathrm{R}_{\mathrm{t}}$ : 7:17 (program V).

\section{Compound $\mathbf{C}$ : Gallic acid}

Colorless needles, recrystallized from $\mathrm{MeOH}-$ $\mathrm{H}_{2} \mathrm{O}, \mathrm{mp} 240{ }^{\circ} \mathrm{C}$;

TLC R $\mathrm{R}_{\mathrm{f}}$ : 0.44 (HPTLC Si $60 \mathrm{~L}$, program I), 0.46 (HPTLC $\mathrm{NH}_{2}$, program II), 0.37 (HPTLC DIOL, program III), 0.89 (HPTLC RP-18, eluent IV); brawn under $\mathrm{UV}_{365}$, dark blue after spraying with $\mathrm{FeCl}_{3}$ reagent, yellow-brown with bis-diazotized sulfanilamide; HPLC $\mathrm{R}_{\mathrm{t}}$ : 4:14 (program V).

Compound D: Brevifolin carboxylic acid

Yellow powder, recrystallized from $\mathrm{MeOH}, \mathrm{mp}$. > $310^{\circ} \mathrm{C}$;

$\mathrm{M}_{\mathrm{r}}$ 292.18, ESI-MS $m / z$ : neg. ion. 291.1[M-H] ${ }^{-}$, pos. ion $293[\mathrm{M}+\mathrm{H}]^{+}$;

TLC $\mathrm{R}_{\mathrm{f}}: 0.20$ (HPTLC $\mathrm{NH}_{2}$, program II), 0.36 (HPTLC RP-18, eluent IV); violet under $\mathrm{UV}_{365}$, yellow-green after spraying with $\mathrm{FeCl}_{3}$ reagent, pink with bis-diazotized sulfanilamide; HPLC $\mathrm{R}_{\mathrm{t}}$ : 15:25 (program $\mathrm{V})$; a solution of $\mathrm{D}(5 \mathrm{mg})$ in distilled $\mathrm{H}_{2} \mathrm{O}(3 \mathrm{ml})$ was heated in a fused glass tube at $140{ }^{\circ} \mathrm{C}$ for $1 \mathrm{~h}$, and the precipitate was recrystal- 
lized from $\mathrm{MeOH}$ to afford brevifolin, which was identified by comparison (TLC, HPLC) with compound $\mathrm{E}$;

UV $\lambda_{\max }(\mathrm{MeOH}): 279,350,362 \mathrm{p} \mathrm{nm} ;$ IR $v_{\max }$ $(\mathrm{KBr}): 3200,1708,1648,1620,1598,1550,1526$, 1484, 1390, 1260, 1204, 1142, 1096, $930 \mathrm{~cm}^{-1} ;{ }^{1} \mathrm{H}$ NMR $\left(\mathrm{CD}_{3} \mathrm{COCD}_{3}+\mathrm{D}_{2} \mathrm{O}\right)$ \&: $7.76(\mathrm{~s}, 1 \mathrm{H}, \mathrm{H}-6)$, 4.88-4.86 (t, 1H, H-1), 3.01 (s, 2H, H-2); ${ }^{13} \mathrm{C}$ NMR $\left(\mathrm{CD}_{3} \mathrm{COCD}_{3}+\mathrm{D}_{2} \mathrm{O}\right) \quad \delta: 195.68 \quad(\mathrm{C}-3), \quad 174.73$ $\left(\mathrm{CO}_{2} \mathrm{H}\right) 161.68$ (C-5), 149.54 (C-3a), 145.62 (C-9), 143.94 (C-7), 141.18 (C-8), 140.59 (C-9a), 115.98 (C-9b), 113.89 (C-5a), 109.13 (C-6), 42.06 (C-1), 37.67 (C-2).

\section{Compound E: Brevifolin}

Yellowish powder, recrystallized from $\mathrm{MeOH}, \mathrm{mp}$. $>310^{\circ} \mathrm{C}$;

$\mathrm{M}_{\mathrm{r}}$ 248.18, LSI-MS $m / z$ : pos. ion. $249[\mathrm{M}+\mathrm{H}]^{+}$;

TLC $\mathrm{R}_{\mathrm{f}}: 0.60$ (HPTLC $\mathrm{NH}_{2}$, program II), 0.22 (HPTLC DIOL, program III), 0.16 (HPTLC RP18 , eluent IV); w $\mathrm{UV}_{365}$ violet under $\mathrm{UV}_{365}$, gray after spraying with $\mathrm{FeCl}_{3}$ reagent, pink with bisdiazotized sulfanilamide; HPLC $\mathrm{R}_{\mathrm{t}}$ : 13:43 (program V);

Ahn D., Putt D., Kresty L., Stoner G.-D., Fromm D. and Hollenberg P.-F. (1996), The effects of dietary ellagic acid on rat hepatic and esophageal mucosol cytochromes P450 and phase II enzymes. Carcinogenesis 17, $821-828$.

Chung J.-G. (1998), Inhibitory actions of ellagic acid on growth and arylamine $\mathrm{N}$-acetyl-transferase activity in strains of Helicobacter pylori from peptic ulcer patients. Microbios 93, 115-127.

Chung K.-T., Lu Z. and Chou M.-W. (1998), Mechanism of inhibition of tannic acid and related compounds on the growth of intestinal bacteria. Food Chem. Toxicol. 36, 1053-1060.

Fecka I., Gasiorowski K. and Brokos B. (1997), Analiza fitochemiczna i ocena immunotropowej aktywnosci frakcji polifenolowej z ziela iglicy pospolitej (Erodium cicutarium (L.) L'Herit.) Herba Polonica 43, 214-221.

Hatano T., Edamatus R., Hiramatsu M., Mori A., Fujita Y., Yasuhara T., Yoshida T. and Okuda T. (1989), Effects of the interaction of tannins with co-existing substances. VI. Effects of tannins and related polyphenols on superoxide anion radical, and 1,1-diphenyl-2picrylhydrazyl radical. Chem. Pharm. Bull., 37, 2016-2021.

Hatano T., Yasuhara T., Yoshihara R., Agata I., Noro T. and Okuda T. (1990), Effects of interaction of tannins with co-existing substances. VII. Inhibitory effects of tannins and related polyphenols on xantine oxidase. Chem. Pharm. Bull., 38, 1224-1229.
UV $\lambda_{\max }(\mathrm{MeOH}): 276,348,366 \mathrm{p} n$ m; IR $v_{\max }$ (KBr): 3600-2600, 1680, 1620, 1580, 1510, 1400, 1300, $11801125,1090,1040,1000,920,800,770$ $\mathrm{cm}^{-1} ;{ }^{1} \mathrm{H}$ NMR (DMSO-d) $\delta: ~ 7.28$ (s, 1H, H-6 ), 3.18 (m, 2H, H-1), 2.4 (d, 2H, H-2); ${ }^{13} \mathrm{C}$ NMR

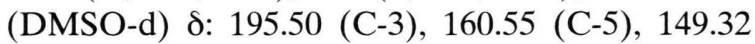
(C-3a), 144.97 (C-9), 144.24 (C-7), 141.43 (C-8), 140.31 (C-9a), 115.44 (C-9a), 113.09 (C-5a), 107.97 (C-6), 33.00 (C-2), 23.82 (C-1).

\section{Compound $\mathbf{F}$ : Ellagic acid}

Yellowish powder, recrystallized from $\mathrm{MeOH}$, mp. $>310^{\circ} \mathrm{C}$;

$\mathrm{M}_{\mathrm{r}}$ 302, LSI-MS $m / z$ : neg. ion. $300.8[\mathrm{M}-\mathrm{H}]^{-}$;

TLC $\mathrm{R}_{\mathrm{f}}: 0.17$ (HPTLC $\mathrm{NH}_{2}$, program II), 0.11 (HPTLC DIOL, program III), 0.15 (HPTLC RP18 , eluent IV) violet under $\mathrm{UV}_{365}$, yellow-green after spraying with $\mathrm{FeCl}_{3}$ reagent, yellow with bisdiazotized sulfanilamide; HPLC $\mathrm{R}_{\mathrm{t}}$ : 16:04 (program V); UV $\lambda_{\max }(\mathrm{MeOH}): 253,365 \mathrm{~nm}$; IR $v_{\max }$ $(\mathrm{KBr}): 3420-2400,1710,1625,1590,1505,1435$, $1400,1345,1260,1200,1115,1060,930,890,815$, $760 \mathrm{~cm}^{-1}$.

Kane C.-J., Menna J.-H. and Yeh Y.-C. (1988a), Methyl gallate, methyl-3,4,5-trihydroxy-benzoate, is a potent and highly specific inhibitor of Herpes simplex virus in vitro. I. Purification and characterization of methyl gallate from Sapium sebiferum. Biosci. Rep. 8, 85-94.

Kane C.-J., Menna J.-H., Sung C.-C. and Yeh Y.-C. (1988b), Methyl gallate, methyl-3,4,5-trihydroxybenzoate, is a potent and highly specific inhibitor of $\mathrm{Her}$ pes simplex virus in vitro. II. Antiviral activity of methyl gallate and its derivatives. Bioscience Rep. 8, 95-102.

Kimura Y., Okuda H., Okuda T., Yoschida T., Hatano T. and Arichi S. (1983), Studies on the activities of tannins and related compounds of medicinal plants and drugs. II. Effects of various tannins and related compounds on adrenaline-induced lipolysis in fat cells. (1). Chem. Pharm. Bull. 31, 2497-2500.

Kimura Y., Okuda H., Okuda T., Yoshida T., Hatano T. and Arichi S. (1983), Studies on the activities of tannins and related compounds of medicinal plants and drugs. III. Effects of various tannins and related compounds on adrenocorticotropic hormone-induced lipolysis and insulin-induced lipogenesis from glucose in fat cells. Chem. Pharm. Bull. 31, 2501-2506.

Kolodziej H., Kayser O., Latte K.-L. and Ferreira D. (1999), Evaluation of the antimicrobial potency of tannins and related compounds using the microdilution broth method. Planta Med. 65, 444-446. 
Klocke J.-A., Wagenen B. and Balandrin M.-F. (1986), The ellagitannin geraniin and its hydrolysis products isolated as insect growth inhibitors from semi-arid land plants. Phytochemistry 25, 85-91.

Lamaison J.-L., Petitjean-Fraytet C. and Carnat A. (1993), Teneurs en polyphenols et activites antioxydantes chez les Geraniaceae francaises. Plantes medicinales et phytotherapie 26, 130-134.

Lin J.-H. and Lin M.-F (1997), Tannins and related compounds from Erodium moschatum (L.) L'Her. J. Food Drug Anal. 5 (4), 347-354.

Lis-Balchin M. (1993), The essential oils of Pelargonium grossularioides and Erodium cicutarium (Geraniaceae). J. Essent. Oil. 5, 317-318.

Lis-Balchin M. and Hart S.-L. (1994) Pharmacological actions of extracts of Pelargonium grossularioides and Erodium cicutarium. J. Herbs Sp. Med. Plants 8, 41-48.

Murakami S., Isobe Y., Kijima H., Nagai H., Muramata M. and Otomo S. (1991), Inhibition of gastric $\mathrm{H}+, \mathrm{K}(+)$-ATPase and acid secretion by ellagic acid. Planta Med. 57, 305-308.

Nawwar Mahmoud A.-M., Hussein Sahar A.-M. and Merfoft I. (1994), NMR spectral analysis of polyphenols from Punica granatum. Phytochemistry 36, 793-798.

Nogaki A., Satoh K. Iwasaka K., Takano H., Takahama M., Ida Y. and Sakagami H.(1998), Radical intensity and cytotoxic activity of curcumin and gallic acid. Anticancer Res. 18, 3487-3491.

Okuda T., Kimura Y., Yoshida T., Hatano T., Okuda H. and Arichi S. (1983), Studies on the activities of tannins and related compounds of medicinal plants and drugs. I. Inhibitory effects of lipid peroxidation in mitochondria and microsomes of liver. Chem. Pharm. Bull. 31, 1625-1631.

Okuda T., Yoshida T. and Hatano T. (1989a), New methods of analyzing tannins. J. Nat. Prod. 52, 1-31.

Okuda T., Yoshida T. and Hatano T. (1989b), Ellagitannins as active constituents of medicinal plants. Planta Med. 55, 117-122.

Okuda T., Yoshida T. and Mori K. (1975), Brevifolin, corilagin and other phenols from Geranium thunbergii. Phytochemistry 14, 1877-1878.

Perchellet J.-P., Gali H.-U., Perchellet E.-M., Klish D.S. and Armbrust A.-D. (1992), Antitumor-promoting activities of tannic acid, ellagic acid, and several gallic acid derivatives in mouse skin. Basic Life Sci. 59, $783-801$
Sakagami H. and Satoh K. (1997a), Prooxidant action of two antioxidants: ascorbic acid and gallic acid. Anticancer Res. 17, 221-224.

Sakagami H., Satoh K., Kadofuku T. and Takeda M. (1997b), Methionine oxidation and apoptosis induction by ascorbate, gallate and hydrogen peroxide. Anticancer Res. 17, 2565-1570.

Sakaguchi N., Inoue M. and Ogihara Y. (1998), Reactive oxygen species and intercellular $\mathrm{Ca}^{2+}$, common signals for apoptosis induced by gallic acid. Biochem. Pharmacol. 55, 1973-1981.

Sakaguchi N., Inoue M., Isuzugawa K., Ogihara Y. and Hosaka K. (1999), Cell death-inducing activity by gallic acid derivatives. Biol. Pharm. Bull. 22, 471-475.

Saleh N.-A.-M., El-Karemy Z.-A.-R., Ragaa M.-M.-A. and Abdel-Aziz F.-A. (1983), A chemosystematic study of some Geraniaceae. Phytochemistry 22, 2501-2505.

Shimizu M., Horie S., Terashima S., Ueno H., Hayashi T., Arisawa M., Suzuki S., Yoshizaki M. and Morita N. (1989), Studies on aldose reductase inhibitors from natural products. II. Active components of a paraguayan crude drug "Para-parai mi," Phyllanthus niruri. Chem. Pharm. Bull. 37, 2531-2532.

Sroka Z., Rzadkowska-Bodalska H. and Mazol I. (1994), Antioxidative effect of extracts from Erodium cicutarium L. Z. Naturforsch. 49c 881-884.

Take Y., Inouye Y., Nakamura S., Allaudeen H.-S. and Kubo A. (1989), Comparative studies of the inhibitory properties of antibiotics on human immunodeficiency virus and avian myeloblastosis virus reverse transcriptases and cellular DNA polymerases. J. Antibiotics 42, 105-115.

Van Sumere C.-F. and Cottenie J. (1972), Recent Advances in Phytochemistry, Appleton Century-Crofts, New York.

Zielinska-Janczylik J., Sypula A., Budko E. and Rzadkowska-Bodalska H. (1987), Iterferonogenic and antiviral effect of extracts from Erodium cicutarium. Arch. Immun. Ther. 35, 211-22.

Zielinska-Janczylik J., Sypula A., Budko E. and Rzadkowska-Bodalska H. (1988), Iterferonogenic and antiviral effect of extracts from Erodium cicutarium. II. Modulatory activity of Erodium cicutarium extracts. Arch. Immun. Ther. 36, 527-536. 